\title{
Evaluation of Ferula Assa-Foetida Accessions for Germination Parameters Under Cold Stratification to Overcome Seed Dormancy and Effect of Media Mixtures on Seedling Growth
}

\author{
Ashok Kumar ( $\nabla$ ashok@ihbt.res.in ) \\ Institute of Himalayan Bioresource Technology \\ Ravi Kumar \\ Institute of Himalayan Bioresource Technology \\ Satbeer Singh \\ Institute of Himalayan Bioresource Technology \\ Sahil Sharma \\ Institute of Himalayan Bioresource Technology \\ Sanatsujat Singh \\ Institute of Himalayan Bioresource Technology \\ Sanjay Kumar \\ Institute of Himalayan Bioresource Technology
}

\section{Research Article}

Keywords: Seed dormancy, chilling, germination, genotypes, Apiaceae and Ferula assa-foetida.

Posted Date: December 3rd, 2020

DOI: https://doi.org/10.21203/rs.3.rs-112608/v1

License: (a) (i) This work is licensed under a Creative Commons Attribution 4.0 International License.

Read Full License 


\section{Evaluation of Ferula assa-foetida accessions for germination parameters \\ 2 under cold stratification to overcome seed dormancy and effect of media 3 mixtures on seedling growth}

4 Ashok Kumar*1, Ravi Kumar ${ }^{1}$, Satbeer Singh ${ }^{1}$, Sahil Sharma ${ }^{1}$, Sanatsujat Singh ${ }^{1}$ and Sanjay 5 Kumar $^{2}$

$6{ }^{1}$ Agrotechnology Division, Council of Scientific and Industrial Research - Institute of Himalayan

7 Bioresource Technology (CSIR-IHBT), Palampur 176061 (HP), India

$8 \quad{ }^{2}$ Director, (CSIR-IHBT), Palampur 176061 (HP), India

9 *Corresponding author: Ashok Kumar, Tel.: +91 9418835423

10 Email address: ashok@ihbt.res.in; akyadavihbt@gmail.com

\section{ABSTRACT}

12 Ferula assa-foetida L. is a perennial of Apiaceae family having seed dormancy which inhibits

13 the germination. Oleo-gum resin obtained from the rhizomes of Ferula assa-foetida plant has

14 several medicinal properties and used for the treatment of various diseases, pharmaceutical

15 industries and in cooking of food in some countries. In present study, three different temperature

16 treatments $\left(5^{\circ}, 15^{\circ}\right.$ and $\left.25^{\circ} \mathrm{C}\right)$ were used to break seed dormancy in six Ferula assa-foetida

17 accessions repeatedly for two years. Also the seedling survival rate with other morphological

18 parameters like plant height, no. of leaves, leaf width, leaf length, root length and root diameter

19 were observed on 3 month old seedlings in six different media mixtures during year 2019-20.

20 The germination ranges from 3.63 (EC968466 at $25^{\circ} \mathrm{C}$ ) to 81.88 percent $\left(\mathrm{EC} 966538\right.$ at $\left.5^{\circ} \mathrm{C}\right)$ with

21 an average of 31.14 percent over all temperatures and genotypes. The mean germination time

22 was ranged from 19.69 to 42.71 days with an average of 30.14 days. The highest germination

$23(66.9 \%)$ and least mean germination time was observed at $5^{\circ} \mathrm{C}(20.85)$ which showed that this

24 crop required a $5^{\circ} \mathrm{C}$ chilling treatment of about 20 days for breaking seed dormancy. The results

25 pertaining to seedling survival experiment showed that media mixture of sand, soil, FYM and 26 cocopeat (1:2:2:1 and 1:1:1:1 ratio) gave higher seedling survival rate (87.66\%) and other 27 morphological traits. It was also observed that the genotype EC966538 and EC968470 were the 
best performer for overall germination as well as seedling survival parameters and could be used as base population in future selection and improvement breeding programs.

Keywords: Seed dormancy, chilling, germination, genotypes, Apiaceae and Ferula assa-foetida.

Ferula assa-foetida L. is a small perennial monocarpic herb belonging to family Apiaceae (Umbelliferae) and commonly known as "Heeng" in Hindi ${ }^{1}$. The plant height is about 1-1.5 meter in length, large size compound leaves and a large size thick taproot with root hairs is present and has a pungent smell. This plant is native to Iran and Afghanistan ${ }^{2,3}$. About 170 species are found all over the world and 60 species of Ferula assa-foetida are geographically distributed around North Africa, Central Asia and Europe ${ }^{4}$. This species is distributed at an elevation between $2000-4000 \mathrm{~m}$ above mean sea level, with an annual rainfall of $250-350 \mathrm{~mm}^{5}$. Two species of genus Ferula i.e. Ferula alliacea and Ferula jaeschkeana are found in India ${ }^{6}$. The oleo-gum resin is present in the fleshy tap roots and this exudate extracted from the roots is called asafoetida. F. assa-foetida is one of the most significant plant of Iran and Afghanistan ${ }^{7}$ because of high export demand for its oleo-gum resin. It has medicinal use in traditional medicines ${ }^{8}$. Asafoetida plays an important role in cooking food as a condiment and in medicine for the treatment of various diseases in India, China, Nepal, Tibet and Iran. The extract of asafoetida is used to treat various diseases viz. Respiratory infections urinary, gastrointestinal and emmenagogues and also used to diagnose for a snake bite, insect bite and worm infection due to bite $^{9,10}$. It is also antispasmodic, carminative and stimulant, diuretic, expectorant, anthelmintic and slightly laxative ${ }^{11}$. The oleo-gum resin of asafoetida contains $25 \%$ gum, $62 \%$ oleo-resin and approximately $3-7 \%$ essential oil ${ }^{12}$.

49 The main problem with the medicinal plants which are native to arid lands is that they germinate and grow well within their habitat or native environment, but fails to show good germination or growth in another environment ${ }^{13}$. For every plant, germination is the most important stage in its 52 life cycle, which controls changes in its population with major useful consequences ${ }^{14}$. Apiaceae

53 family shows very poor germination ability because of seed dormancy ${ }^{15,16}$. Seed dormancy is a 54 state when a viable seed failure to complete germination ${ }^{17,18}$. It is an innate feature of seeds 55 which regulates germination and completion of the plant life cycle ${ }^{19,20}$. But this period of the 56 seed dormancy could be cut short by giving stratified cold treatments to the imbibed seeds. $F$. 
57 assa-foetida seeds are difficult to germinate and take a long time period to germinate seed due to 58 seed dormancy. Two types of seed dormancy have occurred as primary that are internal and 59 external. The internal seed dormancy was belonging to physiological dormancy which can be

60 removed by the chilling, chemical, hormonal and heating treatments but from all the treatments 61 chilling treatment shows the best result to break seed dormancy ${ }^{21,22,23}$. To break seed dormancy

62 there are different methods to germinate dormant seeds ${ }^{24}$. Chilling treatment plays a very

63 important role to break seed dormancy in many species of Apiaceae family ${ }^{22}$ and enhances the

64 germination and speed of germination in dormant seeds.

65 However, germination of Ferula assa-foetida does not occur easily because of seed dormancy.

66 Therefore, a systematic study is necessary to standardize germination parameter for a seed

67 propagated plant having dormancy. Keeping this in view, the study was undertaken with the

68 objectives to determine the effect of cold temperature stratification and genotypic variation on

69 seed dormancy and also to identify suitable media mixture for seedling emergence and growth.

\section{$70 \quad$ Result and Discussion}

71 All the six accessions of Ferula assa-foetida were examined for seed viability, germination and 72 seedling survival under various experiments during 2018 and 2019 (Fig. 1a and 1b) The results 73 pertaining to seed viability, germination, germination parameters and seedling survival rate are 74 given as in following headings.

\section{Seed viability}

76 Seed viability was examined in both the years in three tests repetitions. The results of analysis of 77 variance (ANOVA) showed that the accessions were significantly different for seed viability 78 (Table 2). However, the tests repetitions were found non-significant and suggested that the seed 79 viability was not degraded over a time period of 18 months. Overall, 72.22 percent of seed 80 viability (ranged from 56.00 to $92.00 \%$ ) was observed (Table 3). The average highest seed 81 viability was observed for EC968470 (84\%) and EC966538 (84\%), while the lowest one was 82 observed for EC968469 (60\%).

\section{Seed Germination}


84 The experiment of seed germination of six Ferula assa-foetida accessions were examined in 85 2018-19 and 2019-20 (Fig. 1b). The germination data of both the years 2018-19 and 2019-20 were analyzed individually as well as pooled after conducted Bartlett test to verify the homogeneity assumption for analysis of variance (ANOVA). The different temperature treatments, accessions and their interaction were found highly significant for all the parameters studied (Table 2). The results pertaining to germination, germination parameters and seedling survival rate are given as in following headings.

\section{Effect of various temperature treatments on germination}

92 The pooled and individual analysis of variance (ANOVA) for both the years 2018 and 2019 93 showed significant difference $(\mathrm{p} \leq 0.01)$ for temperature treatments (Table 4$)$. The germination

94 ranges from 3.63 percent $\left(\mathrm{EC} 968466\right.$ at $\left.25^{\circ} \mathrm{C}\right)$ to 81.88 percent $\left(\mathrm{EC} 966538\right.$ at $\left.5^{\circ} \mathrm{C}\right)$ with an 95 average of 31.14 percent over all temperatures and accessions. The average seed germination 96 percentage for all the accessions was highest (Table 5) at $5^{\circ} \mathrm{C}(66.90 \%)$ than $15^{\circ} \mathrm{C}(21.23 \%)$ and $9725^{\circ} \mathrm{C}(5.30 \%)$. The highly significant results of temperature treatments showed that seeds of $F$. 98 assa-foetida require chilling treatment of $5^{\circ} \mathrm{C}$ for their germination. This indicates physiological 99 endogenous dormancy in which factors within embryo inhibits seed germination and require 100 chilling treatment (cold stratification) to initiate germination. This is most common form of seed 101 dormancy in angiosperm plants ${ }^{26,43,44}$. Chilling temperature generally increase the production of 102 germination promoting hormones thereby shifting the balance among promotors and inhibitors 103 towards growth promotors ${ }^{45,46}$. In recent studies, down regulation of ABA and up regulation of 104 GA content in Hydysarum scoparium seeds after cold stratification ${ }^{47}$. It is also important to 105 obtain further valid information on plant growth promoting hormones for $F$. assa-foetida seed 106 germination ${ }^{48}$. The significant positive effect of chilling treatment for breaking seed dormancy 107 was also reported in F. assa-foetida ${ }^{49}$, Ferula gummosa and Ferula ovina ${ }^{50}$. In Bunium persicum 108 species from same Apiaceae family were observed similar results ${ }^{51}$.

\section{Effect of genotypes on germination}

110 Genotypes and their interaction with temperature were significantly different $(\mathrm{p} \leq 0.01)$ for 111 germination percentage in pooled as well as individual analysis of variance (ANOVA) for both 112 the years 2018-19 and 2019-20 (Table 4). The maximum germination (81.88\%) was observed in 
113 EC966538 accession at $5^{\circ} \mathrm{C}$, while EC968469 accession showed lowest germination (55.50\%) at 114 the same $\left(5^{\circ} \mathrm{C}\right)$ level of temperature. In case of adverse high temperature of $25^{\circ} \mathrm{C}$, the accession 115 EC966538 showed maximum germination (8.13\%), while EC968466 had very poor germination

$116(3.63 \%)$ at this adverse temperature (Table 5) and (Fig. 2). The results of genotypic effect on 117 germination showed that the accession EC966538 has consistently higher germination 118 percentage among all the accessions in all temperature treatments. Seed dormancy is the major 119 challenge in F. assa-foetida and other Ferula species $52,53,54,5$ and genetic background of this 120 accession (EC966538) could be used in future germination improvement breeding programs.

\section{Other germination parameters}

122 Seeds of F. assa-foetida are not germinated in a single flush, and involvement of multi-level seed 123 dormancy causes continuous germination up to several days even with some favorable 124 environment. Hence, germination percentage should not be only the single parameter to access 125 the germination capability of this crop. Thus, in present study we have observed several other 126 parameters to identify best accession and environment for good germination. These parameters 127 are germination index (GI), mean germination time (MGT), mean daily germination (MDG), 128 coefficient of velocity of germination $(\mathrm{CVG})$, peak value $(\mathrm{PV})$, germination value $(\mathrm{GV})$, days to $12925 \%$ germination (DG25\%), days to $50 \%$ germination (DG50\%), days to $75 \%$ germination 130 (DG75\%), radical length (RDL) and seed vigor index (SVI).

131 The pooled and individual analysis of variance (ANOVA) for both the years 2018 and 2019 132 showed significant difference $(\mathrm{p} \leq 0.01)$ for temperature treatments, genotypes and their 133 interaction for all the other germination parameters studied (Table 4). Mean germination time 134 (MGT) measures mean time required by any seed sample to initiate and terminate germination. 135 Lower is the value of MGT, faster a seed lot has germinated ${ }^{55}$. The results pertaining to mean 136 germination time (MGT) showed that germination was achieved very fast (Table 3) and (Fig. 3) 137 at $5^{\circ} \mathrm{C}$ temperature treatment (20.85 days) than at $15^{\circ} \mathrm{C}(29.88)$ and $25^{\circ} \mathrm{C}(39.71)$. MGT ranges 138 from 19.69 days (EC968469 at $5^{\circ} \mathrm{C}$ ) to 42.71 days (EC968466 at $25^{\circ} \mathrm{C}$ ) with an average of 30.14 139 days over all temperatures and genotypes. The germination rate per day measured as mean daily 140 germination (MDG) was also highest for $5^{\circ} \mathrm{C}\left(1.48\right.$ seedlings/day) than at $15^{\circ} \mathrm{C}(0.47)$ and $25^{\circ} \mathrm{C}$ 141 (0.12). Over, all the temperature treatments, the accession EC968469 has lowest mean 
142 germination time (28.80 days) at 0.59 seedlings per day germination rate. Similarly, the days to $14325 \%, 50 \%$ and $75 \%$ germination were also found lowest at $5^{\circ} \mathrm{C}(15.19,18.54$ and 24.06 days, 144 respectively). The accession EC966538 has highest per day germination rate (0.84 145 seedlings/day). Whereas, mean germination time decreased significantly by increasing 146 temperature from $15^{\circ} \mathrm{C}$ to $20^{\circ} \mathrm{C}$ under constant temperature treatment ${ }^{56}$.

147 Germination index (GI) is a measure of both germination percentage and speed of germination. It 148 gives maximum weightage to early geminating seeds and less weightage to late germination ${ }^{55}$. 149 The GI ranged from 0.09 (EC968466 at $\left.25^{\circ} \mathrm{C}\right)$ to 3.94 (EC966538 at $5^{\circ} \mathrm{C}$ ) with an average of 1501.44 over all temperatures and genotypes. The average germination index for all the genotypes 151 was highest (Table 5) at $5^{\circ} \mathrm{C}(3.47)$ than $15^{\circ} \mathrm{C}(0.73)$ and $25^{\circ} \mathrm{C}(0.14)$.

152 Coefficient of velocity of germination $(\mathrm{CVG})$ denotes the rapidity of germination and increases 153 with germination of seeds and time required for their germination is reduced ${ }^{55}$. CVG ranged 154 from 2.35 (EC968466 at $25^{\circ} \mathrm{C}$ ) to 5.08 (EC968469 and EC968470 at $5^{\circ} \mathrm{C}$ ) with an average of 1553.59 over all temperatures and genotypes. Recently, the mean germination time, germination 156 index and coefficient variation of germination were studied for Magnolia grandiflora plant after 157 cold stratification ${ }^{40}$. The results pertaining to PV, GV and SVI were also in accordance to results 158 of mean germination time and per day germination rate i.e. the temperature treatment of $5^{\circ} \mathrm{C}$ and 159 accession EC966538 followed by EC968470 were found best performer (Table 3). Also, the 160 radical length (Fig. 4 and Fig. 5) and seed vigor index was highest at $5^{\circ} \mathrm{C}(2.55 \mathrm{~cm}$ and 1.70 , 161 respectively) followed by $15^{\circ} \mathrm{C}(1.71 \mathrm{~cm}$ and 0.36,$)$. However, in overall genotypic effects, the 162 highest radical length and seed vigor was found for EC968470 (1.87 cm and 0.84, respectively).

163 These seed germination parameters also studied in some Himalayan leguminous and actinorhizal 164 plants $^{57,58}$.

\section{Seedling survival rate}

166 To check the seedling survival rate, all newly germinated plants were examined in the year 201916720 under six different media mixtures (Table 1) for various morphological traits viz. plant height $168(\mathrm{~cm})$, number of leaves, leaf length $(\mathrm{cm})$, leaf width $(\mathrm{cm})$, root length $(\mathrm{cm})$ and root diameter 169 (mm). The results of analysis of variance for seedling survival traits showed that all the 170 genotypes and media mixtures were highly significant $(\mathrm{p}<0.01)$ for all traits studied (Table 6).

171 While, genotype $\times$ media interaction effect was non-significant for number of leaves, leaf length 
172 and root diameter. It showed that the studied accessions were genetically diverse for seedling

173 survivals and could be utilized as base population for further selection and breeding programs.

174 The mean performance of different media mixture and genotypes showed that the accession 175 EC968466 in media M4 and EC968467 in M5 have highest seedling survival (91.50\%) (Table 5) 176 and (Fig. 6 and Fig. 7). Over all media mixtures, M5 has the highest seedling survival rate 177 (87.66\%), followed by M4 (87.08\%). Media M4 has highest plant height (21.49 cm), number of 178 leaves $(5.27)$, leaf length $(9.22 \mathrm{~cm})$, leaf width $(6.58 \mathrm{~cm})$, root length $(11.93 \mathrm{~cm})$ and root 179 diameter $(5.36 \mathrm{~mm})$. It showed that the combination of soil, sand, FYM and cocopeat in 1:2:2:1 180 ratio was the best mixture to attained maximum survival of $F$. assa-foetida seedlings. While, 181 media M6, which was only soil has lowest seedling survival rate (46.50) and also found lowest 182 for all other seedling survival parameters, which indicated that this crop needs a survival media 183 at initial stage to get good seedling establishment.

184 Genotypic effects on seedling establishment showed that accession EC968467 has highest 185 survival rate $(75.94 \%)$ and number of leaves (5.17) but lowest root diameter (4.16 mm). 186 Accession EC968470 has highest plant height $(15.15 \mathrm{~cm})$ and root length $(9.67 \mathrm{~cm})$, while 187 accession EC966538 was best for other leaf parameters i.e. number of leaves, leaf length and leaf 188 width Table 7. It was observed that the accession EC968469 has lowest seedling survival rate $189(65.33 \%)$, leaf length $(6.58 \mathrm{~cm})$, leaf width $(4.88 \mathrm{~cm})$ and root length $(8.30 \mathrm{~cm})$. vermiculite as 190 suitable media for seed germination of Jatropha Curcas ${ }^{57}$. Some Himalayan leguminous and 191 actinorhizal plants shows higher germination on moistened filter paper as compared to mixture 192 of soil and sand ${ }^{58}$.

\section{Summary}

194 According to present study, we concluded that the chilling treatment at $5^{\circ} \mathrm{C}$ is more effective for 195 dormancy breaking of Ferula asafoetida seeds. It shows that dormancy is caused by an inhibiting 196 chilling in the interior or exterior surface layers of seeds. Further studies are required to explain 197 the agro-practices to cultivate this endangered plant. Cold treatment at $5^{\circ} \mathrm{C}$ for about 20 days was 198 appropriate to breaking seed dormancy and maximum seed germination by. Our finding suggests 199 that cold treatments are commercial and effortlessly applicable by poor farmers and nursery 200 manual workers in developing bulk planting material, over costly supplementary technicalities 
201 and plant growth regulators (PGR). The results of germination in Laboratory condition can also

202 be applied to propagation of plants that would help conservation programs within the study area.

203 But maximum germination of $F$. asafoetida through seed is very difficult and almost very low.

204 Media mixture of sand, soil, FYM and cocopeat (1:2:2:1 and 1:1:1:1 ratio) gave higher seedling

205 survival. It was also observed that the accession EC966538 and EC968470 were the best

206 performer for overall germination as well as seedling survival parameters.

\section{Material and methods}

\section{Plant material}

209 Six accessions of Ferula assa-foetida (Heeng) seeds used in the study were EC966538, 210 EC968466, EC968467, EC968468, EC968469 and EC968470 procured through National Bureau 211 of Plant Genetic Resources, New Delhi. The seeds were cleaned with removing the chaff 212 material and damaged or immature seeds. Healthy and mature seeds separated from the seed lot 213 were stored under ambient laboratory conditions prior to use in the experiments. Weight of 100 214 seed was 1.82g. The present study was conducted during 2018-2019 and 2019-2020 in the 215 laboratory of Agrotechnology Division, CSIR-Institute of Himalayan Bioresource Technology, 216 Palampur (Himachal Pradesh), India (N 326.36546' latitude, E 76 33.52122' longitude at an 217 altitude of $1310.0 \mathrm{~m}$ with average annual rainfall $2493 \mathrm{~mm}$ and average annual temperature is $21819.1^{\circ} \mathrm{C}$ ). All the experiments of germination and seedling survival were conducted in Completely 219 Randomized Design (CRD) design in with four replications.

\section{Seed viability test}

221 Seeds of $F$. assa-foetida were examined for seed viability with the help of Tetrazolium test 222 (2,3,5-tri-phenyltetrazolium chloride). For that, 1\% Tetrazolium solution was prepared by adding 223 1g 2,3,5-tri-phenyl-2H-tetrazolium chloride (TTC) in $100 \mathrm{ml}$ of doubled distilled water in a 224 brown bottle, mixed well and confirmed the $\mathrm{pH}$ of the solution at 7. Further, four replicates of 25 225 seeds from each accessions were dissected using a magnifying lens. Then the dissected seeds 226 with embryo were kept in $1 \%$ tetrazolium solution and incubate at room temperature for 24 hours 227 in dark ${ }^{19}$. Seeds were evaluated on their staining pattern and colour intensity as the bright red 228 color stained seeds considered as viable while partially or light stained seeds were considered as 
229 non-viable ${ }^{25,26}$. The seed viability test was repeated three times in every 6 months during the 230 study period i.e. in 2018, 2019-I and 2019-II.

\section{$231 \quad$ Surface sterilization}

232 Healthy seeds of $F$. assa-foetida selected on the basis of their shape and size were surface 233 sterilized by pre-washing with tap water for $1 \mathrm{~h}$ and then soaking the seeds in $1 \%$ sodium 234 hypochlorite solution $(\mathrm{NaOCl})$ with tween-20 (2 drops $/ 100 \mathrm{ml})$ for $25 \mathrm{~min}$ and then washed with 235 sterilized double distilled water to remove traces of sterilizing agents before putting in petri236 dishes.

\section{Seed germination}

238 To overcome the seed dormancy in F. assa-foetida, an experiment with different temperatures 239 and accessions was conducted during 2018-19 and 2019-20. For the stratification treatments, 240 seeds of six different accessions were kept at three controlled and constant temperature 241 treatments i.e. $5^{\circ} \mathrm{C}, 15^{\circ} \mathrm{C}$ and $25^{\circ} \mathrm{C}$ for germination. For germination tests, four replicates of 25

242 seeds were incubated in petri dishes lined with double layer of sterile Whatman no.1 filter paper 243 moistened with $5 \mathrm{ml}$ double distilled water. All the petri plates were sealed with parafilm and 244 seeds were allowed to germinate at $5^{\circ} \mathrm{C}$ temperature in a cold chamber (Blue star company), $24515^{\circ} \mathrm{C}$ and $25^{\circ} \mathrm{C}$ temperature in growth room for a time period of 45 days. During the incubation 246 period, filter papers were kept moist with distilled water. The germination counts were observed 247 daily from first to last day of maximum seed germination ${ }^{27,28,29,30}$. Seeds at the time of radicle 248 emergence were considered germinated ${ }^{31}$ and an interval 45 days was found enough to get 249 maximum germination and differentiation of non-dormant seeds from dormant ones ${ }^{22,32,33}$.

\section{Germination parameters}

\section{Seed germination}

252 Seed germination (\%) was recorded after 45 days of chilling treatment and under different 253 temperature. The total number of germinated seeds were counted and germination was computed 254 in percentage using following formula: 


$$
\text { Germination }(\%)=\frac{\text { Number of seeds germinated }}{\text { Total number of seeds sown }} \times 100
$$

\section{Mean germination time}

257 Mean germination time (MGT) is considered as an indicator of seedling emergence in field and 258 calculated by using formula ${ }^{34}$.

$$
\text { Mean germination time (Seed per day) }=\frac{\sum F_{i} n_{i}}{\mathrm{~N}}
$$

260 Where, $\mathrm{n}_{\mathrm{i}}$ is the number of germinated seeds on $\mathrm{f}_{\mathrm{i}}^{\text {th }}$ day of observation during germination time 261 (from 0 to 45 days) and $\mathrm{N}$ is the total number of germinated seeds.

\section{Coefficient of velocity of germination}

263 Coefficient of velocity of germination $(\mathrm{CVG})$ was computed using following formula ${ }^{35}$.

$$
\mathrm{CVG}=\frac{N_{1}+N_{2}+\ldots+N_{i}}{100 \times\left(N_{1} T_{1}+\ldots+N_{i} T_{i}\right)}
$$

265 Where $\mathrm{N}_{\mathrm{i}}$ is the number of seeds germinated on $\mathrm{T}_{\mathrm{i}}^{\text {th }}$ day of observation from seeding.

\section{Germination index}

267 Germination index (GI) was calculated by using formula ${ }^{36}$.

$$
\text { Germination Index }(\mathrm{GI})=\left(45 \times \mathrm{N}_{1}\right)+\left(44 \times \mathrm{N}_{2}\right)+\ldots+\left(1 \times \mathrm{N}_{45}\right)
$$

269 Where $\mathrm{N}_{1}, \mathrm{~N}_{2} \ldots \mathrm{N}_{45}$ is the number of germinated seeds counted every day till $45^{\text {th }}$ day and the 270 constants $(45,44 \ldots .1$ etc $)$ are the weights provided.

\section{$271 \quad$ Mean daily germination}

272 Mean daily germination (MDG) was calculated by using formula ${ }^{37}$.

$$
\text { Mean daily germination }(M D G)=\frac{\text { Total number of germinated seeds }}{\text { Total number of days }}
$$

\section{Peak value}


275 Peak value (PV) was calculated by using given formula ${ }^{37}$.

$$
\text { Peak value }(\mathrm{PV})=\frac{\text { Highest seed germinated }}{\text { number of days }}
$$

\section{Germination Value}

278 Germination Value (GV) was calculated by using formula ${ }^{38,39,40}$.

$$
\text { Germination Value }(\mathrm{GV})=\left(\sum \mathrm{DGS} / \mathrm{N}\right) \times \mathrm{GP} / 10
$$

280 Where DGS is the ratio of cumulative germination percentage to the number of days from 281 seeding, $\mathrm{N}$ is days counts from the germination initiation and GP is final germination percentage.

\section{Seed vigor index}

283 The seed vigor index (SVI) was computed using following formula ${ }^{41}$.

$$
\text { Seed vigor index }\left(\mathrm{V}_{\mathrm{i}}\right)=\frac{L s \times \mathrm{Pg}}{100}
$$

285 Where $\mathrm{V}_{\mathrm{i}}$ is the vigor index, Ls is the length of seedling and $\mathrm{Pg}$ is germination percentage.

Days to $25 \%, 50 \%$ and $75 \%$ germination

287 Days to $25 \%, 50 \%$ and $75 \%$ germination were calculated when 25,50 and 75 percent 288 germination of Ferula assa-foetida seeds was achieved.

\section{Radical length}

290 Radical length was measured with the help of meter scale in centimeter $(\mathrm{cm})$.

\section{Media Mixtures}

292 After cold stratification treatment germinating seeds of all the six accessions were transferred to 293 different media mixtures under glasshouse conditions to study the survival and growth of the 294 germinating seedlings Table 1.

\section{Morphological data collection}


After three months, data from different media mixtures on seedling survival and other growth 297 parameters viz. plant height $(\mathrm{cm})$, number of leaves, leaf length $(\mathrm{cm})$, leaf width $(\mathrm{cm})$, root length 298 (cm) were recorded with the help of geometrical scale and root diameter was measured with the 299 help of Vernier calliper in millimeter ( $\mathrm{mm})$.

300 Seedling survival rate was calculated after three months of transferred seedling in the poly 301 sleeves using following formula.

302 Survival rate $=$ (Total number of survived seedling / Total number of transferred seedlings $) \times$ $303 \quad 100$

\section{Statistical analysis}

305 Analysis of variance (ANOVA) for all the three experiments i.e. seed viability, germination and 306 seedling survival were computed separately using PROC ANOVA in SAS v9.4 ${ }^{42}$ by considering 307 all the variables as fixed effect.

\section{References}

309 1. Srinivasan, K. Spices for taste and flavour: Nutraceuticals for Human Health. In: De AK, ed. 310 Spices: The Elixir of Life. New Delhi, India. chapter- 2 43-6243-62 (2011).

311 2. Ross, I.A. Medicinal Plants of the World: Chemical Constituents, Traditional and Modern 312 Medicinal Uses. 3nd ed. USA, Humana Press Inc, 287 (2007).

313 3. Leaman, D.J. Medicinal plant conservation. Newsletter of the medicinal plant specialist 314 group of the IUCN species survival commission. Silphion 13, 24-26 (2006).

315 4. Sahebkar, A., Iranshahi, M. Biological activities of essential oils from the genus Ferula 316 (Apiaceae). Asian Biomedicine 4, 835-847, https://doi.org/10.2478/abm-2010-0110 (2010).

317 5. Nadjafi, F., Bannayan, M., Rastgoo, M., Tabrizi, L. Seed germination and dormancy 318 breaking techniques for Ferula gummosa and Teucrium polium. Journal of Arid 319 Environments 64, 542-547, https://doi.org/10.1016/j.jaridenv.2005.06.009 (2006).

320 6. Dutt, N.B. Commercial Drugs of India. Thacker, Spink \& Co. Calcutta and Simla 1-256 321 (1928).

322 7. Safaian, N., Shokri, M. Botanical and ecological study of species of the genus Ferula 323 (Medicinal Plants) in Mazandaran province. Acta Horticult 333, 159-167, 324 https://doi.org/10.17660/ActaHortic.1993.333.18 (1993). 
8. Islami-Manuchehri, B. Utilization of non-wood forest production in Iran. Rangeland and Forest Journal 25, 12-20 (1994).

9. Hadidi, K.A., Aburjai, T., Battah, A.K. A comparative study of Ferula hermonis root extracts and sildenafil on copulatory behaviour of male rats. Fitoterapia 74, 242-246 (2003).

10. Shweta, G., Chetna, R., Jinkal, S., Nancy, S., Hitesh, J., 2011. Herbal plants used as contraceptives. International Journal of Current Pharmaceutical Review and Research 2, 4753, http://www.ijcpr.com/PDF (2011).

11. Nadkarni, K.M., Nadkarni, A.K. Indian Materia Medica, Vol. I, Third Revised and Enlarged Edition, popular Book Depot, Bombay (1954).

12. Fatehi, M., Farifteh, F., Fatehi-Hassanabad, Z. Antispasmodic and hypotensive effects of $F$. Foetida gum extract. Journal of Ethnopharmacology 91, 321-324, https://doi.org/10.1016/j.jep.2004.01.002 (2004).

13. Gupta, V. Seed germination and dormancy breaking techniques for indigenous medicinal and aromatic plants. Journal of Medicinal and Aromatic Plants Science 25, 402-407 (2003).

14. Keller, M., Kollmann, J. Effects of seed provenance on germination of herbs for agricultural compensation sites. Agriculture, Ecosystems and Environment 72, 87-99, https://doi.org/10.1016/S0167-8809(98)00167-4 (1999).

15. Zare, A.R., solouki, M., Omidi, M., Irvani, N., Oadzad, A.A., Mahdi, N.N. Effect of various treatments on seed germination and dormancy breaking in Ferula assa-foetida (Assafetida), a threatened medicinal herb. Trakia Journal of Sciences 9,57-61 (2011).

16. Butola, J.S., Badola, H.K. Effect of pre-sowing treatment on seed germination and seedling vigor in Angelica glauca, a threatened medicinal herb. Current Science 87, 796-799, https://www.jstor.org/stable/24109359 (2004).

17. Bewley, J.D. Seed germination and dormancy. Plant Cell 9, 1055- 1066, https://doi.org/10.1105/tpc.9.7.1055 (1997).

18. Koornneef, M., Bentsink, L., Hilhorst, H. Seed dormancy and germination. Current Opinion in Plant Biology 5, 33-36, https://doi.org/10.1016/S1369-5266(01)00219-9 (2002).

19. Shalimu, D., Sun, J., Baskin, C.C., Baskin, J.M., Sun, L., Liu, Y. Changes in oxidative patterns during dormancy break by warm and cold stratification in seeds of an edible fruit tree. AoB Plants 8, 1-13, https://doi.org/10.1093/aobpla/plw024 (2016). 
20. Finch-Savage, W.E., Leubner-Metzger, G. Seed dormancy and the control of germination. New Phytologist 171, 501-523, https://doi.org/10.1111/j.1469-8137.2006.01787.x (2006).

21. Baskin, J.M., Baskin, C.C. Nondeep complex morpho physiological dormancy in seeds of Osmorhiza claytonii (apiaceae). American Journal of Botany 78, 588-593, https://doi.org/10.1002/j.1537-2197.1991.tb15225.x (1991).

22. Baskin, J.M., Baskin, C.C. A classification system for seed dormancy. Seed science Research 14, 1-16, https://doi.org/10.1079/SSR2003150 (2004).

23. Phillips, N., Drost, D., Varga, W. Chemical treatment enhanced seed germination in Perideridia gairdneri. Acta Horticult 618, 477-482 (2003).

24. Gul, B., Ansaria, R., Flowers, T.J., Khan, M.A. Germination strategies of halophyte seeds under salinity. Environmental and Experimental Botany 92, 4-18, https://doi.org/10.1016/j.envexpbot.2012.11.006 (2013).

25. International Seed Testing Association. ISTA working sheets on tetrazolium testing. Vol. I. International Seed Testing Association (ISTA), Bassersdorf, Switzerland (2003).

26. Baskin, C.C., Baskin, J.M. Ecology, biogeography and evolution of dormancy and germination, 2nd edition. San Diego, CA: Elsevier/Academic Press (2014).

27. Kumar, B., Gupta, A.K., Verma, A.K., Dubey, A. Comparative seed germination of Tagetes minuta. Journal of Tropical and Medicinal Plants 9, 149-151 (2008a).

28. Kumar, B., Gupta, A.K., Verma, A.K., Saini, R.K., Khanuja, S.P.S. Comparative germination kinetics and efficiency in Marigold (Tagetes erecta L.) accessions over storage. Journal of Medicinal and Aromatic Plant Science 30, 142-145 (2008b).

29. Kumar, B., Verma, A.K., Ram, G., Singh, H.P., Lal, R.K. Genotype-independent germination-testing procedure for Isabgol. Journal of New Seeds 10, 196-205, https://doi.org/10.1080/15228860903115211 (2009).

30. Kumar, B., Verma, A.K., Ram, G., Singh, H.P., Lal, R.K. Seed germination of five elite genotypes of Papaver somniferum. Journal of Tropical Medicinal Plants 11, 107-112 (2010).

31. Bewley, J.D., Bradford, K.J., Hilhorst, H.W.M., Nonogaki, H. Seeds: Physiology of development, germination and dormancy, 3rd edition. New York, Springer (2013). 
32. Baskin, C.C., Baskin, J.M. Underdeveloped embryos in dwarf seeds and implications for assignment to dormancy class. Seed Science and Research 15, 357-360, http://doi.org/ 10.1079/SSR2005224 (2005).

33. Silveira, F.A.O., Ribeiro, R.C., Soares, S., Rocha, D., Oliveira, C. Physiological dormancy and seed germination inhibitors in Miconia (Melastomataceae). Plant Ecology and Evolution

34. Schelin, M., Tigabu,, M., Erikssn, I., Sawadogo, L. Effect of scarification, gibberellic acid and dry heat treatments on the germination of Balanties aegyptica seeds from the Sudanian savanna in Burkina Faso. Seed Science and Technology 31, 605-617, https://doi.org/10.15258/sst.2003.31.3.10 (2003).

35. Jones, K.W., Sanders, D.C. The influence of soaking pepper seed in water or potassium salt solutions on germination at three temperatures. Seed Science and Technology 11, 97-102, https://www.jstor.org/stable/23432941 (1987).

36. Bench, A.R., Fenner, M., Edwards, P. Changes in germinability, ABA content and ABA embryonic sensitivity in developing seeds of Sorghum bicolor (L.) Moench induced by water stress during grain filling. New Phytologist 118, 339-347, https://doi.org/10.1111/j.14698137.1991.tb00986.x (1991).

37. Czabator, F.J. Germination value: an index combining speed and completeness of pine seed germination. Forest Science 8, 386-396, https://doi.org/10.1093/forestscience/8.4.386 (1962).

38. Djavanshir, K., Pourbeik, H. Germination value-a new formula. Silvae Genetica 25, 79-83 (1976).

39. Swaminathan, C., Revathy, R. Improving seed germination in Sapindus emarginatus vahl. Pinnacle Agricultural Research \& Management, 1-3 (2013).

40. Fetouh, M.I., Hassan, F.A. Seed germination criteria and seedling characteristics of Magnolia grandiflora L. trees after cold stratification treatments. International Journal of Current Microbiology and Applied Science 3, 235-241 (2014).

41. Abdul-Baki, A.A., James, J.D. Vigor Determination in Soybean Seed by Multiple Criteria. Crop Science 13, 630-633, https://doi.org/10.2135/cropsci1973.0011183X001300060013x (1973). 
42. SAS Institute Inc. SAS® University Edition Quick Start Guide for Students with Visual Impairments. Cary, NC, USA (2018).

416 43. Tiwari, A.K., Bisht, P.S., Kumar, V., Yadav, L.B. Effect of pulsing with PGRs on leaf 417 yellowing and other senescence indicators of Alstroemeria cut flowers. Annals of $418 \quad$ Horticulture 3, 34-38 (2010).

419 44. Tiwari, A.K., Tiwari, T.N., Prashad, S.R. Seed dormancy in ornamental plants: A review. $420 \quad$ Indian Journal of Agricultural Sciences 86, 580-92 (2016).

45. Erker, B. Seed dormancy mechanisms. Colorado Seed Laboratory, Department of Soil and Crop Sciences (2010).

46. Rehman, S., Park, I.H. Effect of scarification, GA and chilling on the germination of golden rain- tree (Koelreuteria Paniculata Laxm.) seeds. Scientia Horticulturae 85, 319-324, https://doi.org/10.1016/S0304-4238(00)00126-6 (2000).

47. Su, L., Lan, Q., Pritchard, H.W., Xue, H. and Wang, X., 2016. Reactive oxygen species induced by cold stratification promote germination of Hedysarum scoparium seeds. Plant Physiology and Biochemistry 109, 406-415 (2016).

48. Lombraña, A.C., Porceddu, M., Dettori, C.A., Bacchetta, G. Discovering the type of seed

49. Otroshy, M., Zamani, A., Khodambashi, M., Ebrahimi, M. and Struik, P.C. Effect of exogenous hormones and chilling on dormancy breaking of seeds of asafoetida (Ferula assafoetida L.). Research Journal of Seed Science 2, 9-15, http://dx.doi.org/10.3923/rjss.2009.9.15 (2009).

50. Keshtkar, H.R., Azarnivand, H., Etemadc, V., Moosavi, S.S. Seed dormancy-breaking and germination requirements of Ferula ovina and Ferula gummosa. Desert 13, 45-51, https://dx.doi.org/10.22059/jdesert.2008.27174 (2008).

443 https://doi.org/10.12980/APJTB.4.2014APJTB-2014-0042 (2014). 
444 52. Rajabian, T., Saboura, A., Hasani, B., Falah Hosseini, H. Effects of GA3 and chilling on seed 445 germination of Ferula assa-foetida, as a medicinal plant. Iranian Journal of Medicinal and $446 \quad$ Aromatic Plants 23, 391-404 (2007).

447 53. Keshtkar, H.R., Azarnivand, H., Atashi, H. Effect of prechilling and GA3 on seed 448 germination of Ferula assa-foetida and Prangos ferulacea. Seed Science and Technology 37, 449 464-468, https://doi.org/10.15258/sst.2009.37.2.19 (2009).

450 54. Amoaghaei, R. The effect of GA3 and Moist-Chilling on Seed Dormancy Breaking of Ferula 451 ovina Boiss. Journal of Water and Soil Conservation 11, 471-482, 452 http://jstnar.iut.ac.ir/article-1-720-en.html (2007).

453 55. Al-Mudaris, M.A. Notes on various parameters recording the speed of seed germination. Der 454 Tropenlandwirt-Journal of Agriculture in the Tropics and Subtropics 99, 147-154 (1998).

455 56. Zangoie, M., Parsa, S., Mahmoodi, M., Jami Al-Ahmadi, M., Sanjari, G. Effect of 456 temperature regimes on seed germination Asafoetida (Ferula assafoetida L.). Plant Breeding 457 and Seed Science 69, 59-67, https://doi: 10.1515./plass-2015-0006 (2014).

458 57. Gairola, K.C., Nautiyal, A.R., Dwivedi, A.K. Effect of Temperatures and Germination Media 459 on Seed Germination of Jatropha Curcas Linn. Advances in Bioresearch 2, 66-71 (2011).

460 58. Bargali, K., Singh, S.P. Germination behaviour of some leguminous and actinorhizal plants 461 of Himalaya: Effect of temperature and medium. Tropical Ecology 48, 99-105 (2007). 
Figures

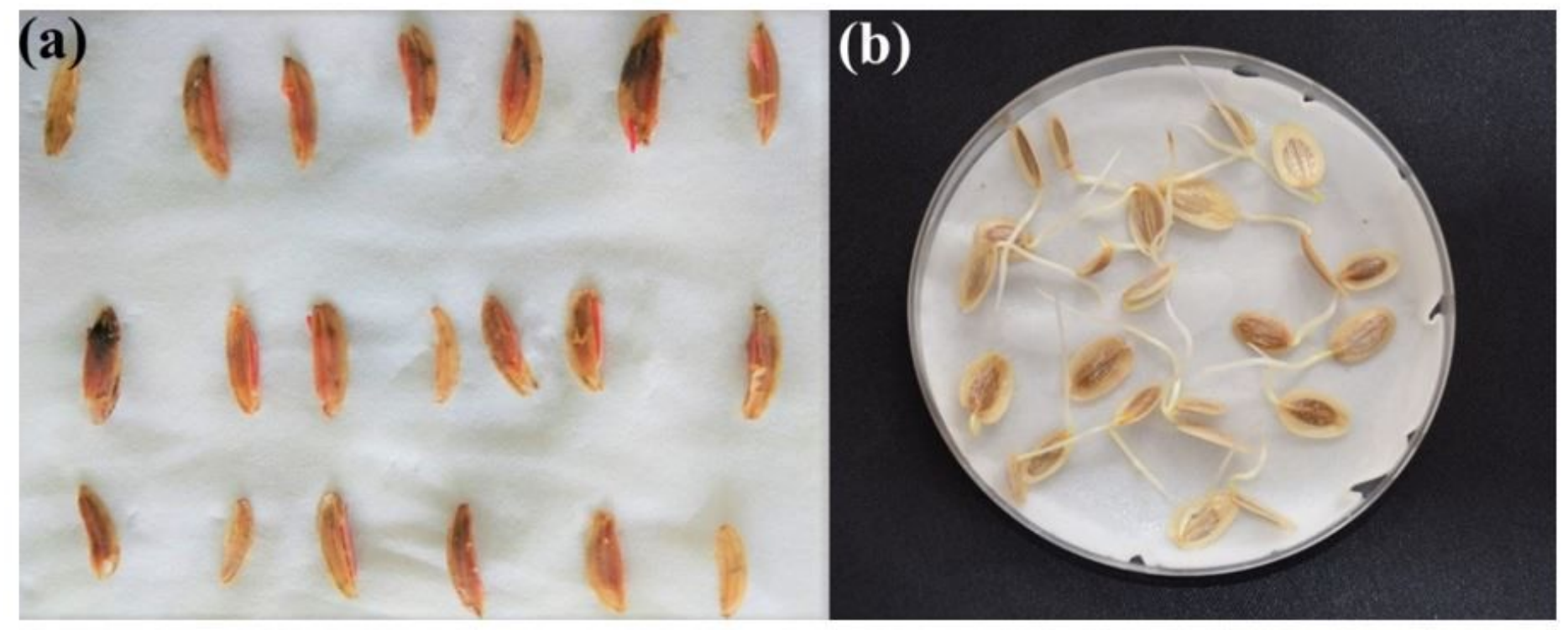

Figure 1

TTC stained seed (a) and germinated seedling (b) of Ferula assa-foetida

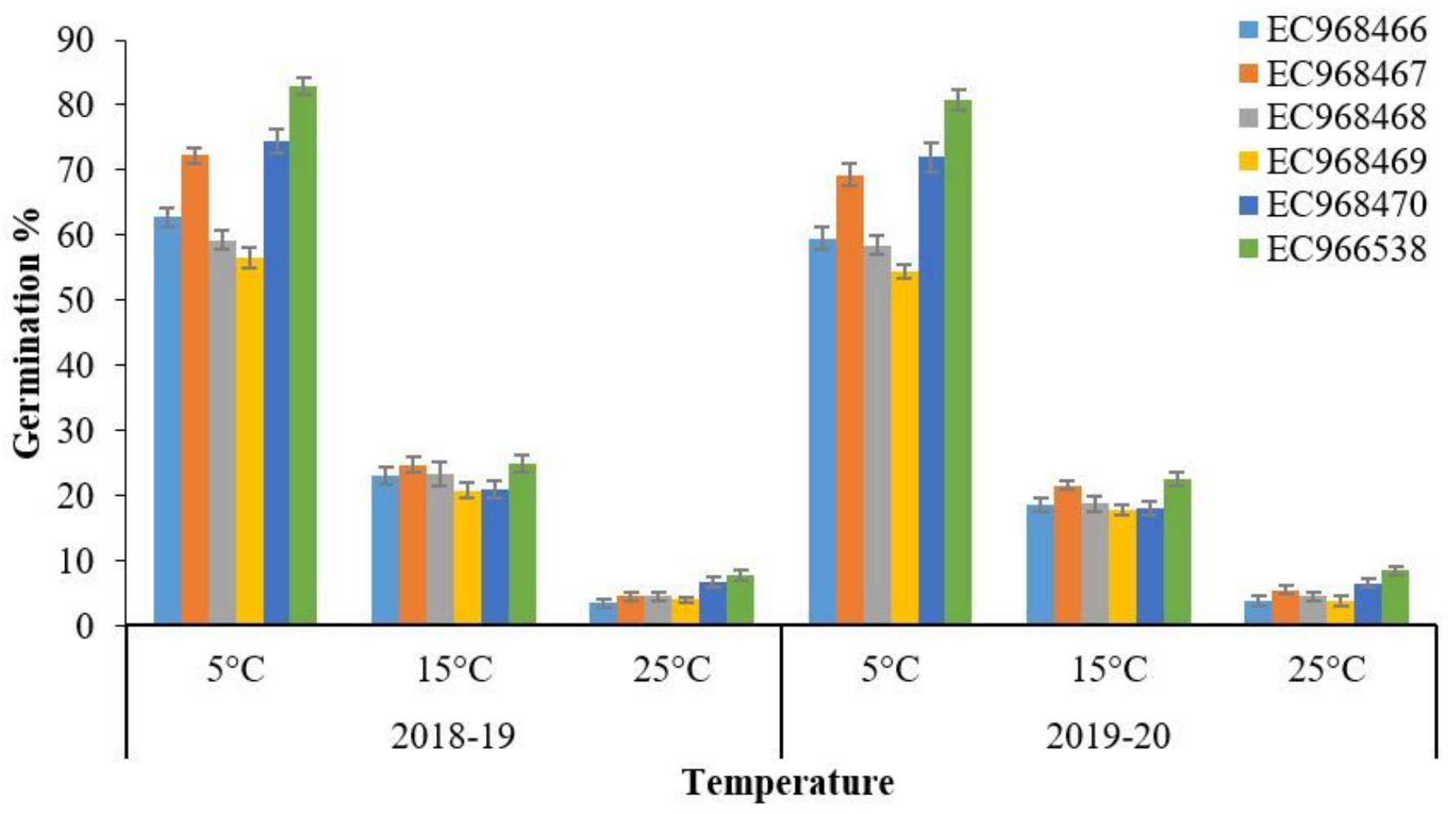

Figure 2 
Germination (\%) of different accession plotted over different temperature in 2018-19 and 2019-20.

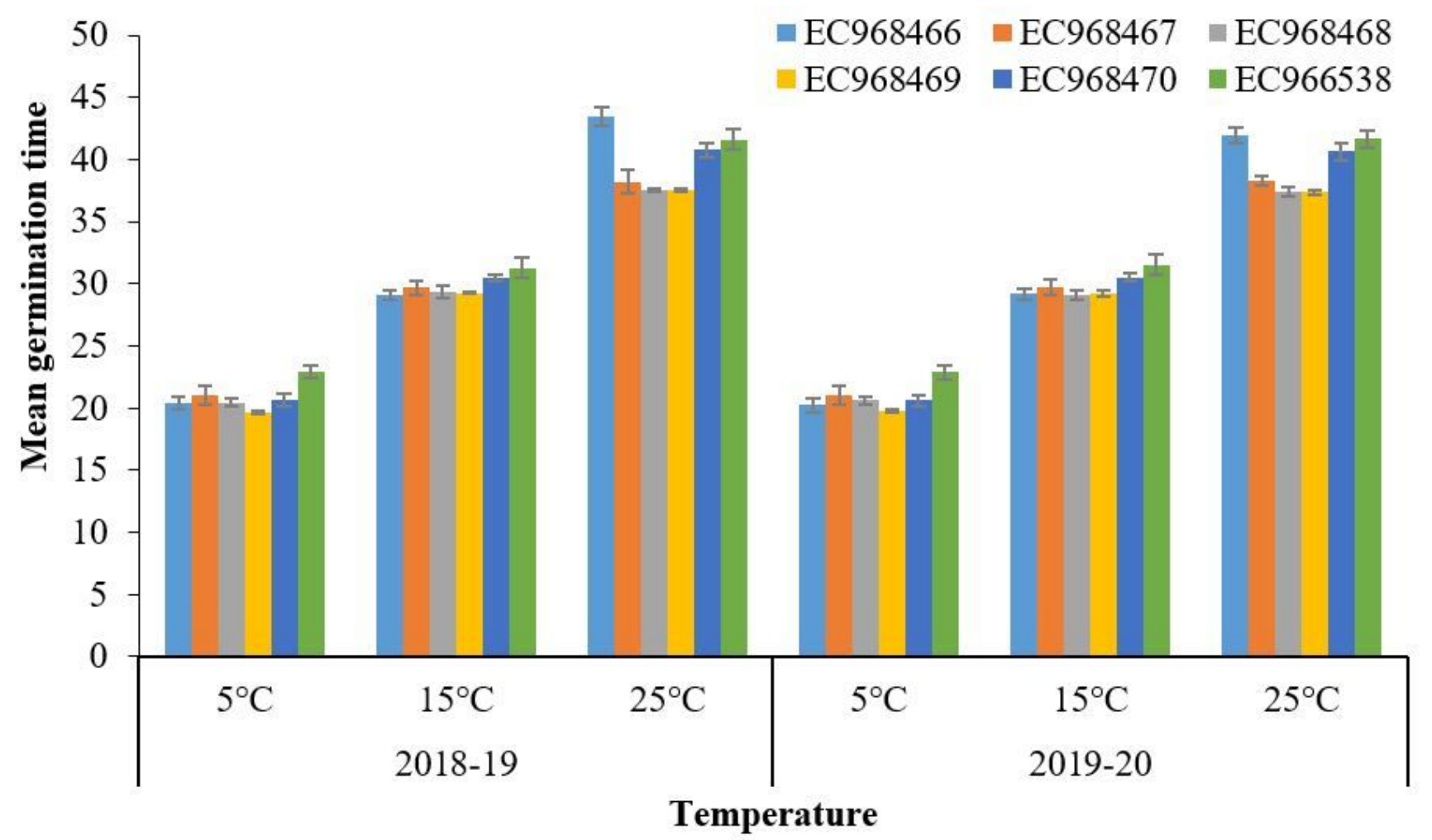

Figure 3

Mean Germination time of different accessions plotted over different temperature in 2018-19 and 201920 


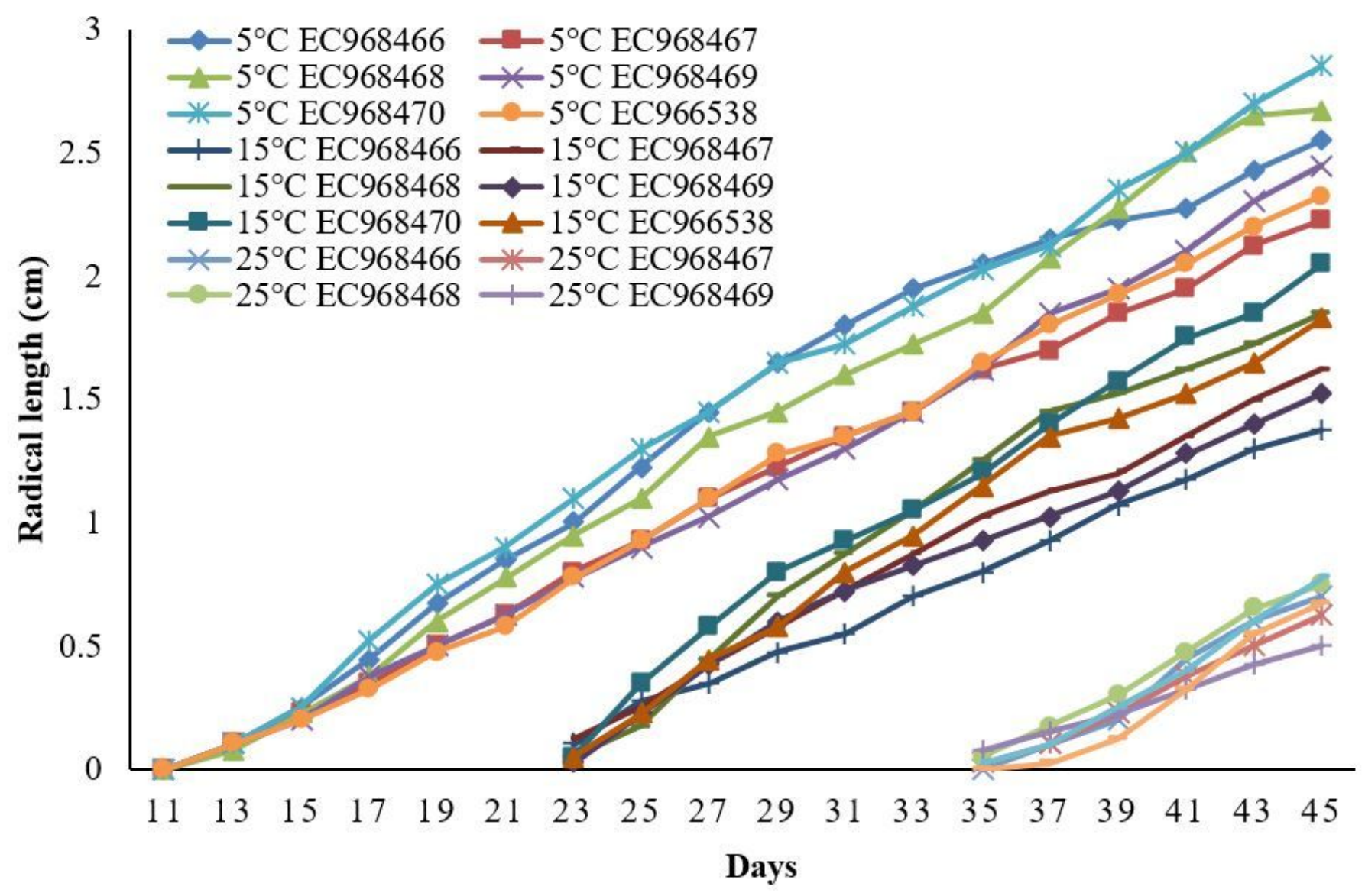

Figure 4

Rate of root emergence per day in year 2018-19. 


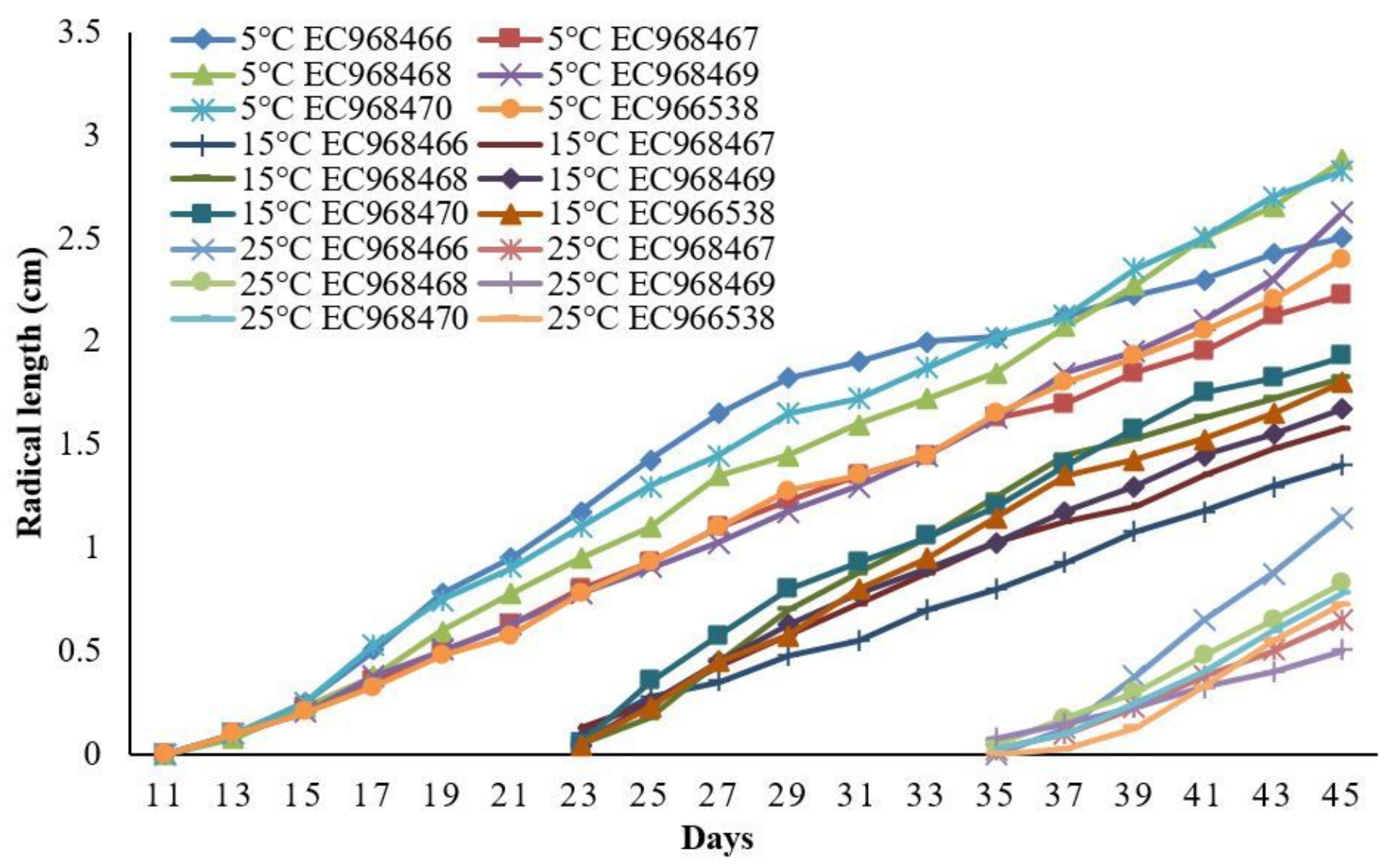

Figure 5

Rate of root emergence per day in year 2019-20. 


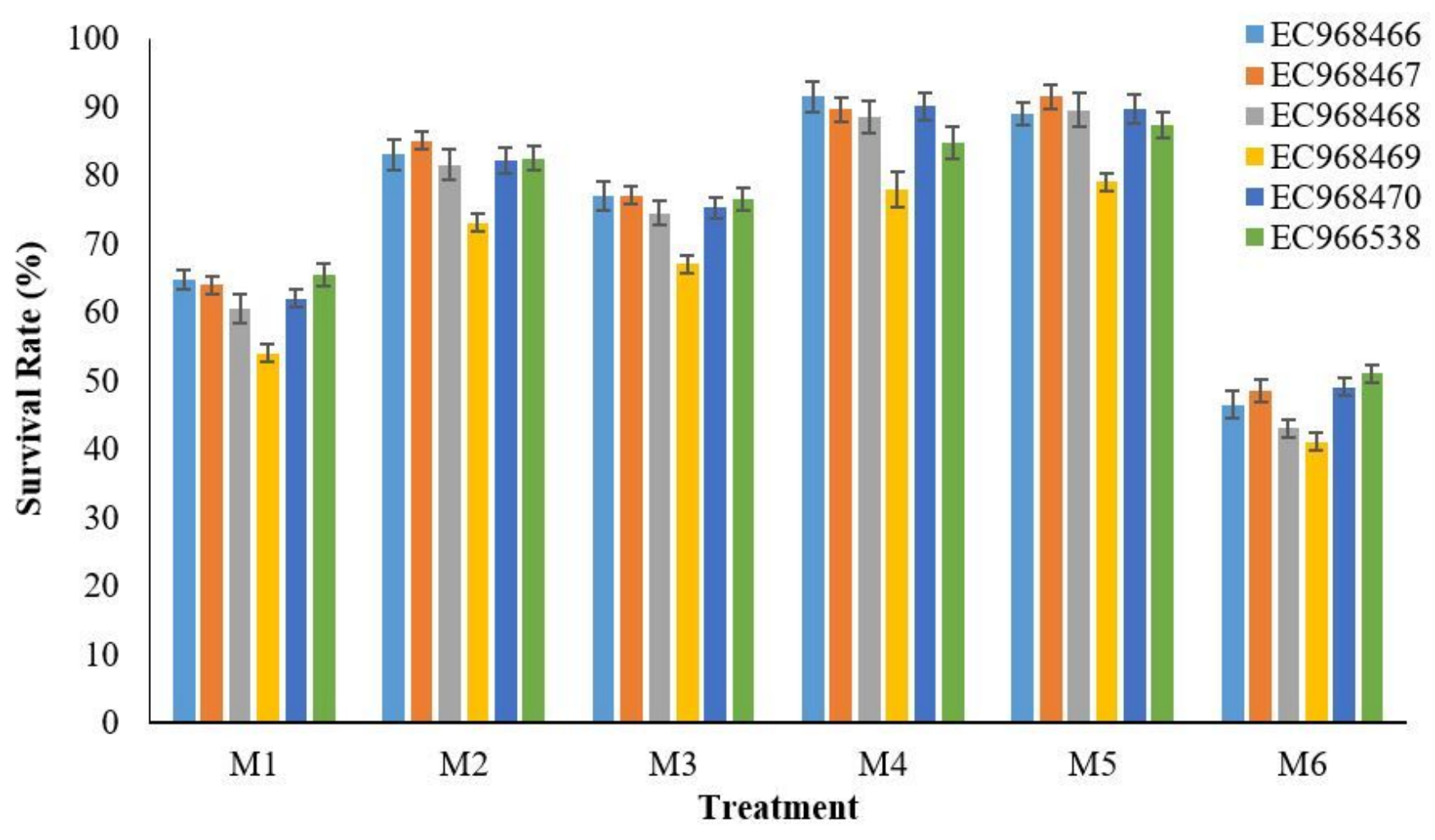

Figure 6

Survival rate of seedling under different media mixture treatments. 


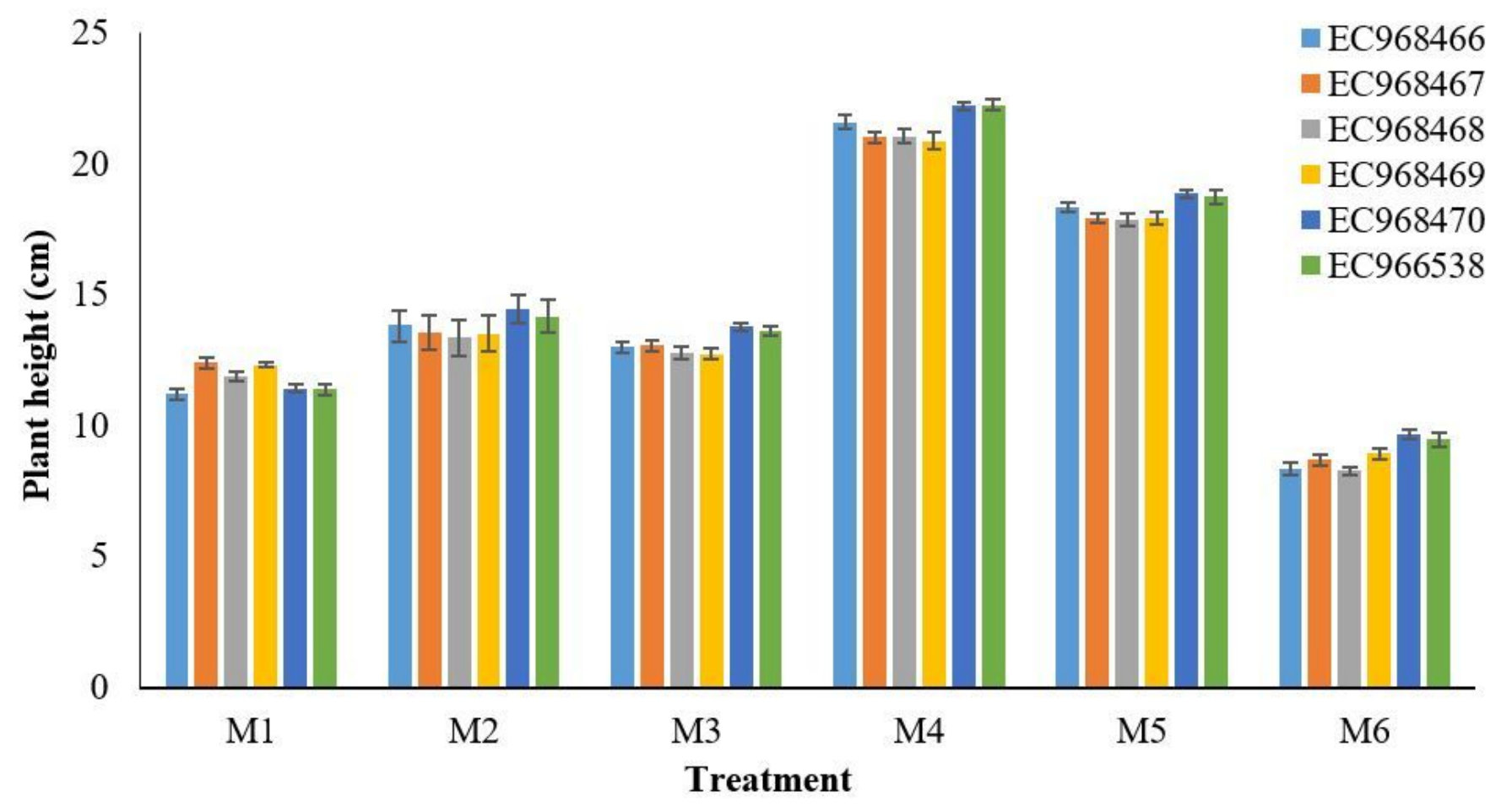

Figure 7

Plant height under different media mixture treatments 